\title{
The adoption of Management Accounting Tools in the Egyptian Manufacturing Sector \\ Traditional vs Contemporary tools
}

Hesham Ahmed Mahmoud Yousef

Ph.D. Student at Cairo University

Assistant Lecturer at Sohag University

Hesham.yousef@commerce.sohag.edu.eg
Prof. Dr. Hanafi Zaki

Professor of Cost and

Management Accounting

Cairo University, Egypt

The Paper extracted from the Ph.D. Dissertation under the Title: Adoption of Management Accounting innovations in the Egyptian Business Environment - Analysis of Obstacles and Motivation

\section{Under Supervision: Prof. Dr. Hanafi Zaki}

\section{Abstract:}

This research tries to discover the status of management accounting practice in the Egyptian business environment, through exploring the usage of the traditional and contemporary management accounting tools in the manufacturing companies of the public business sector.

Findings show that traditional management accounting tools are still dominant in the Egyptian firms, although the adoption of contemporary management accounting tools is considered acceptable compared with other studies conducted in some developing countries.

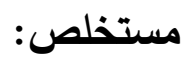

يحاول هذا البحث اكتشاف وضع ممارسات المحاسبة الإدارية في بيئة الأعمال المصرية، من

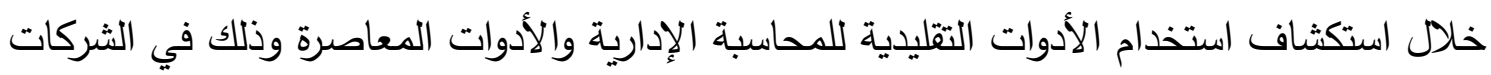
الصناعية التابعة لقطاع الأعمال العام.

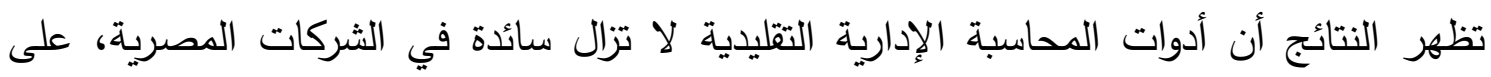

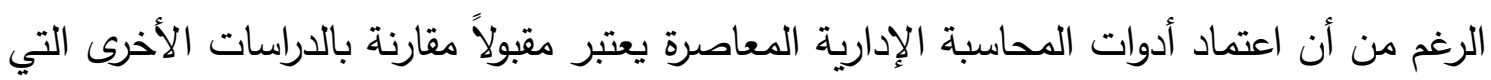
أجريت في بعض البلدان النامية. 


\section{Introduction:}

Over the last three decades, many contemporary management Accounting tools (Management Accounting Innovations- MAIs) have been introduced to business environments. Concepts such as Activity Based Costing (ABC), Balanced Scorecard, Target Costing, Strategic Cost Management and Economic Value Added $\left(\mathrm{EVA}^{\mathrm{TM}}\right)$, Beyond Budgeting are the most accepted and widespread tools, and they highly considered in the management accounting research (Ax and Greve, 2017; Chiwamit, et al, 2017; Busco and Quattrone, 2015; Sisaye, 2015; Ax and Bjørnenak, 2005).

It has been argued that these 'new' accounting techniques have been designed to support modern technologies and new management processes, such as total quality management and lean and just-in-time production systems, pull system, etc. All of this to achieve a competitive advantage in their business environment and globally. As, there is a lack of efficiency and capability of traditional cost and management accounting systems has been the main impetus for recent cost and management accounting innovations (Askarany \& Smith, 2003).

However, many organizations have not adopted these MAIs and there is a lack in the diffusion of these innovations (Abdel-Kader and Luther, 2008). Previous studies indicated that most companies are still using traditional management accounting tools (TMATs) in producing information for decision making (Bromwich \& Bhimani, 1989; Guilding et al, 2000). TMATs is highly quantitative and internally focused (Bromwich \& Bhimani, 1989; Drury, 2004) and because of the changes in manufacturing environment and competition, TMATs has not been able to produce such a dynamic information for the business in today's competitive environment (Bromwich \& Bhimani, 1989; Cooper \& Kaplan, 1988; Guilding et al, 2000).

The failure to produce broad scope information under TMATs would lead managers to limit their focus on operational issues and downplay focus on broader issues relating to competitors, quality of products and customer (Bromwich \& Bhimani, 1989). While TMATs information is deemed important and sufficient for planning, decision making and control in the past, the current landscape has changed and this calls for a demand for 
broad scope information (Cadez \& Guilding, 2008; Kaplan \& Norton, 1996; Heong et al. 2013).

Thus, to fit to the new dynamic and global environment, the employment of new management accounting tools (management accounting innovations- MAIs) is needed. The adoption of MAIs is one of the ranges of new management accounting techniques and approaches that may be used to meet the new challenges facing by companies (Simmonds, 1981).

In the light of the above, the overarching aim of the study is to reach a comprehensive understanding for the state management accounting in one of the developing countries; namely Egypt, through achieving the following:

- Exploring the current use of TMATs in the Egyptian companies, and the satisfaction with these TMATs.

- Exploring the current use of MAIs in the Egyptian companies.

\section{Theoretical Background:}

According to Chandler (1977), management accounting systems (MAS) first appeared in the United States during the nineteenth century. These MAS employed both simple and sophisticated accounting methods. For example, the early management accounting measures were simple but seemed to satisfy the needs of business owners and managers. Simple managerial accounting procedures created during the nineteenth century were used to monitor and evaluate the output of internally directed processes. Cost accounts were used to ascertain the direct labour and overhead costs of converting raw materials into goods. Most of the concepts and techniques used in traditional cost accounting, which is the forerunner to and continues to be at the core of management accounting, were developed in the nineteenth century (Askarany, 2002).

However, until the 1920s, management accounting was not a very important function. Cost accountants, often called works accountants, were generally poorly trained, junior personnel whose main job was to go into the factory in order to gather various data for production managers and for financial accountants. Most of what is now considered within the purview of management accounting was then the exclusive domain of the production manager's aides and industrial engineers with respect to product 
and department cost accounting. Matters of managerial strategy control and strategy were under the control of production and other levels of management. The importance of the income statement gave a spin to cost accounting, which evolved into a decision-making science and became known as management accounting, followed by an increase in its status among the various functions of management (Islam \& Kantor, 2005).

During the nineteenth century scientific management experts also developed new cost accounting procedures to evaluate and control physical and financial efficiency of tasks and processes in complex machine-making firms and to assess the overall profitability of the enterprise (Johnson and Kaplan 1987).

As Johnson and Kaplan reported, most of cost and management accounting procedures were developed during the nineteenth and first quarter of the twentieth centuries. They further stated that before World War I some organisations were trying to develop and use accurate cost accounting systems to trace costs accurately to diverse lines of products. This evidence confirms that even the idea and logic behind activity-based costing for designing an accurate costing method is not new. The application of non-accounting information (financial and non-financial) in management accounting, which has attracted considerable attention in the last two decades is not new either.

Kaplan (1984) in particular claimed that there had been little management accounting innovation since 1925, and that the data produced by management accounting systems reflected external reporting requirements far more than they did based on the reality of the new manufacturing environment. He argued that the manufacturing environment now is very different from what it was before; therefore, different management accounting techniques were required in terms of evaluating both financial and non-financial aspects of manufacturing performance. In addition, Kaplan (1986) indicated that for management accounting systems to provide relevant information for managerial decisions and control they must change in response to any change in manufacturing processes (Leftesi, 2008).

Therefore, since the 1950s more than 30 popular cost and management accounting techniques have been introduced. The majority of these innovations have been introduced during the last two decades. According to 
Hagerty (1997) and Smith (1999), the major developments in management accounting since the 1950s can be explained as follows: (Askarany, 2002)

- 1950s: Discounted cash flows, Total quality management, Cusum charts and Optimum transfer pricing.

- 1960s: Computer technology, Opportunity cost budgeting, Zero-base budgeting, Decision trees, Critical path scheduling, and Management by objectives.

- 1970s: Information economics and agency theory, Just-in-time scheduling, Strategic business units, Experience curves, portfolio management, Materials resource planning, Diversification, Matrix organisation and Product repositioning.

- 1980s: Activity-based costing (ABC), activity-based management $(\mathrm{ABM})$, Strategic management accounting (SMA), Activity management (AM), Life cycle costing (LCC), Target costing, Valueadded management, Theory of constraints, Vertical integration, Private labels and Benchmarking.

- 1990s: Business process reengineering, Quality functional deployment, Balanced scorecard, Outsourcing, Gainsharing, Core competencies, Time-based competition and Learning organisation.

So, it is noticeable that MAIs are introduced as a response for the change in its surrounding business environment and what is good in the past should not be good nowadays, management accounting as a social domain which should be changed based on the changes in the needs of their users. This development led to what is considered as innovations in management accounting, which are the new modern management accounting tools, or Management Accounting Innovations (MAIs).

\section{Research Methodology:}

- This research adopted a quantitative approach, which is one where the investigator primarily uses a positivistic paradigm, uses methodologies (methods) such as experiments and surveys, and collects data on predetermined instruments using closed questions, and uses statistical techniques to analyse the data. It is a deductive approach with an emphasis on testing theories and views social reality as external and objective (Bryman and Bell, 2011). 
- A postal questionnaire was used to collect empirical data. This facilitated access to a large number of respondents and provided sufficient data for statistical analysis.

- I have depended on online services to develop my survey and to send links to respondent to fill the questionnaire, which can increase the response rate, as respondent will fill the questionnaire easily and reaching the respondents will be fast. Especially with the crisis of Covid 19, using electronic questionnaires is the most efficient and effective way to conduct the survey.

- The entire population consists of all public business sector's companies (joint venture manufacturing companies between business sector and state) in the Egyptian business environment. These companies count nearly 124 company (holding and subsidiary), with all public business sector companies are under 9 holding companies, of which 5 holding companies are considered manufacturing under which 93 subsidiary companies, these companies are the focus of the study. Table (1) clarify the response rate, which is very good as the response rate is $81.7 \%$.

\begin{tabular}{|l|c|}
\hline \multicolumn{2}{|c|}{ Table (1): Response rate } \\
\hline $\begin{array}{l}\text { Population size (Egyptian manufacturing companies } \\
\text { in the public business sector) }\end{array}$ & 93 \\
\hline Total usable responses & 76 \\
\hline Response Rate & $\mathbf{8 1 . 7 \%}$ \\
\hline
\end{tabular}

\section{Results:}

\subsection{General Information about the Respondents}

As Table 2 shows most of the respondents are members of the Central auditing Agency as $42 \%$ are financial controllers, as those are the more familiar with all details in the companies. 
Table (2) Respondents' Job Title

\begin{tabular}{|l|c|c|c|}
\hline \multicolumn{1}{|c|}{ Respondent job title } & Frequency & Percent & Rank \\
\hline Financial Controller & 32 & 42.1 & 1 \\
\hline Financial manager & 11 & 14.5 & 2 \\
\hline General manager & 11 & 14.5 & 3 \\
\hline Financial accountant & 6 & 7.9 & 4 \\
\hline Accounting manager & 5 & 6.6 & 5 \\
\hline Cost accountant & 4 & 5.3 & 6 \\
\hline Management accountant & 3 & 3.9 & 4 \\
\hline Internal auditor & 2 & 2.6 & 8 \\
\hline CEO Total & 2 & 2.6 & 9 \\
\hline
\end{tabular}

According to the respondent experience in the current position in the company as shown in table 3,35\% of the respondents have a 5-10 years' experience in their current position, and $27.6 \%$ have more than 15 years' experience, and 10.5 have from 11-15 years' experience, this reflect that nearly $72 \%$ of the respondents have more than 5 years' experience in their position, which mean that respondents are knowledgeable and highly experienced to provide relevant information about their management accounting systems. For the respondents' position, $42 \%$ of the respondents work as financial controller in their companies, with $29 \%$ work as financial manager and general managers, internal auditor, and CEO.

\begin{tabular}{|c|c|c|}
\hline \multicolumn{3}{|c|}{ Table (3) Respondents' experience in current position } \\
\hline Experience Period & Frequency & Percent \\
\hline Less than 5 years & 20 & 26.3 \\
\hline $5-10$ & 27 & 35.5 \\
\hline 11-15 & 8 & 10.5 \\
\hline More than 15 years & 21 & 27.6 \\
\hline Total & 76 & 100.0 \\
\hline
\end{tabular}




\subsection{General Information about the Responding Companies:}

The respondents were asked to provide information about the features of their companies. The following tables summarize the main characteristics in terms of company age and industry type, and ownership.

\begin{tabular}{|c|c|c|c|}
\hline \multicolumn{4}{|c|}{ Table (4) Companies' industry type } \\
\hline $\begin{array}{c}\text { Industry type } \\
\text { (Manufacturing activity) }\end{array}$ & $\begin{array}{c}\text { Frequenc } \\
\mathbf{y}\end{array}$ & $\begin{array}{c}\text { Percen } \\
t\end{array}$ & $\begin{array}{c}\text { Cumulative } \\
\text { Percent }\end{array}$ \\
\hline $\begin{array}{l}\text { Cement and building } \\
\text { materials }\end{array}$ & 9 & 11.8 & 11.8 \\
\hline Chemical & 7 & 9.2 & 21.1 \\
\hline $\begin{array}{l}\text { Construction and contracting } \\
\text { works }\end{array}$ & 15 & 19.7 & 40.8 \\
\hline Cars and motors & 3 & 3.9 & 44.7 \\
\hline Food and drinks & 19 & 25.0 & 69.7 \\
\hline Metal & 5 & 6.6 & 76.3 \\
\hline Oil and gas & 17 & 22.4 & 98.7 \\
\hline Clothes and textile & 1 & 1.3 & 100.0 \\
\hline Total & 76 & & 100.0 \\
\hline
\end{tabular}

\subsection{The Current Usage of Traditional Management Accounting Tools (TMATs):}

In order to cover the horizon of management accounting systems in the Egyptian business environment, it is required to take a look about the usage of traditional management accounting tools nowadays, this will help in recognizing the expectations about the usage of MAIs, for example if the firm do not use cost accounting regularly, so it is predictable that it will be less motivated to depend on the MAIs, so this coverage can help in setting explanations for the position of the MAIs in the business environment.

\subsubsection{Accounting Systems and Costing Practices:}

Firstly, respondents were asked to indicate whether or not they are currently using one accounting system for a variety of purposes, multiple systems for a specific function each, or one system at present, but a plan to adopt more than one accounting system. Table 6-8 shows the result of this investigation. 
Table (5) The number of accounting systems within the surveyed firms

\begin{tabular}{|l|c|c|}
\hline \multicolumn{1}{|c|}{ Number of accounting systems } & Frequency & Percentage \\
\hline Single system & 46 & 60.5 \\
\hline Multiple systems, each for specific functions & 27 & 35.5 \\
\hline $\begin{array}{l}\text { Currently single, but the plan is to implement } \\
\text { multiple }\end{array}$ & 3 & 3.9 \\
\hline \multicolumn{1}{|c|}{ Total } & $\mathbf{7 6}$ & $\mathbf{1 0 0 . 0}$ \\
\hline
\end{tabular}

Table 5 shows that $60.5 \%$ of the respondents indicated that they were currently not using multiple accounting systems, and this result was in line with findings (Emore and Ness, 1991; Triest and Elshahat, 2007; Al Chen et al., 1997; Friedl et al., 2009; Brierley et al., 2007. At the same time, $35.5 \%$ of the respondents indicated that they had adopted multiple systems, and only $3.9 \%$ of the respondents indicated they had a plan to adopt multiple systems.

\subsubsection{The functions of the product costing system:}

According to table 6, 42.9\% of respondents indicate that they use product cost information for external financial reporting, the second function is the product cost control, as $28.6 \%$ of respondents use costing system for product cost control. Functions of product pricing and evaluating new products, are the lowest functions for which costing system is used, with a percentage of $16.2 \%$ and $12.4 \%$ respectively.

Table (6) The functions of the product costing system as replied by the participants

\begin{tabular}{|c|c|c|}
\hline The functions of the cost system & Frequency & Percentage \\
\hline External financial reporting & 45 & $42.9 \%$ \\
\hline Product cost control & 30 & $28.6 \%$ \\
\hline Product pricing & 17 & $16.2 \%$ \\
\hline Evaluation of new product cost & 13 & $12.4 \%$ \\
\hline
\end{tabular}




\subsubsection{Decision-making Practices:}

One of the main traditional tools used in the decision-making practices is cost-volume-profit. Johnson and Kaplan (1987) argued that the main shortcoming of this approach is was that it focuses only on the short term, which mainly serves inventory valuation, even though the current business environment necessitates using sophisticated quantitative tools for longterm planning and decision-making.

\subsubsection{The usage of cost-volume profit (CVP):}

CVP analysis is a simplified model, useful for elementary instruction and for short-run decisions, and it is used to determine how changes in costs and volume affect a company's operating income and net income, although today management functions are more sophisticated, and CVP are considered traditional tools, but the need for CVP and breakeven decision making tools has not gone away (Cafferky, 2010), so respondents were asked to indicate whether or not their firms currently use this technique. Table 7 represents the responses to this question.

Table (7) The extent of the usage of CVP procedure in decision-making Frequency Percent

\begin{tabular}{|c|c|c|}
\hline Yes & 44 & 58 \\
\hline No & 32 & 42 \\
\hline Total & $\mathbf{7 6}$ & $\mathbf{1 0 0}$ \\
\hline
\end{tabular}

Table 7 shows that $58 \%$ of respondents indicated that they use CVP analysis, and this result is unquestionably in line with that reported by several researchers around the world (Clarke, 1992, 1997; Joshi, 2001; Wijewardena and Zoysa, 1999; Shield et al., 1991). A possible explanation for the heavy use of CVP analysis, maybe the preference of the managers within the surveyed firms for short-term decision strategies, or their unfamiliarity to advanced statistical or mathematical techniques.

\subsubsection{Pricing technique (Usage of cost-plus technique):}

Respondent were asked to indicate whether or not their firms used the cost-plus system, as a classical way for setting their product's prices. Table 8 reports the findings. 


\begin{tabular}{|c|c|c|}
\hline \multicolumn{3}{|c|}{$\begin{array}{c}\text { Table (8) The extent of the usage of cost-plus method for sitting } \\
\text { product price }\end{array}$} \\
\hline & Frequency & Percent \\
\hline Yes & 57 & 75 \\
\hline No & 19 & 25 \\
\hline Total & 76 & 100 \\
\hline
\end{tabular}

Table 8 shows that only $25 \%$ of respondents are currently not using the cost-plus technique, while the remaining $75 \%$ of respondents are using it. Also, it is clear from this table that the adoption of the cost-plus method is high amongst Egyptian firms. The heavy adoption of the cost-plus method in the Egyptian firms may indicate the low impact of the demand side (the clients or customers- customers and competitors) for determining firms' product prices, and this may reflect the low effect of the competition power in the Egyptian Business Environment.

\subsubsection{Planning and controlling systems:}

Two main traditional management accounting tools that are used extensively for planning and controlling are standard costing and traditional budgeting, so the current usage of these systems has been examined.

\subsubsection{Standard Costing (SC) System:}

The vast majority of managers are still convinced that standard costing system can serve firms in different areas (such as planning, controlling, decision-making, performance measurement, product pricing, and improving and modifying firm strategies).

Respondents were asked to indicate whether or not their companies were currently utilising standard costing systems. This particular question was posed to evaluate the development in the usage of this system since 1998. Table 6-14 reports the results. 
Table (9) The extent of the usage of standard costing system by the surveyed firms

\begin{tabular}{|c|c|c|}
\hline & Frequency & Percent \\
\hline Yes & 43 & 56.6 \\
\hline No & 33 & 43.4 \\
\hline Total & $\mathbf{7 6}$ & $\mathbf{1 0 0}$ \\
\hline
\end{tabular}

Table 9 shows that $56.6 \%$ of respondents used the SC system, while $43.4 \%$ did not. The result of this study is consistent with the mainstream, in terms of the continuing heavy use of the SC system, as reported in several studies (Drury et al., 1993; Ask and Ax, 1997; Clarke, 1992, 1997; Joshi, 2001; Chun et al., 1996).

\subsubsection{Traditional Budgeting:}

Traditional budgeting appears to have a number of disadvantages, like it is rarely strategically focused and often contradictory, it often precludes responsiveness to change in the companies' environment, the process of budget preparation is time-consuming and costly (Clarke ,2001), however it enjoys widespread use among companies (Hyvonen, 2005; Joshi, 2001; Chenhall and Langfield-Smith; 1998a).

In the light of this, Egyptian manufacturing firms were asked to indicate whether or not their companies used traditional budgeting. Table 10 reports the findings.

Table (10) The extent of the usage of tradition annual budgeting systems

\begin{tabular}{|c|c|c|}
\hline & Frequency & Percent \\
\hline Yes & 69 & 91 \\
\hline No & 7 & 9 \\
\hline Total & $\mathbf{7 6}$ & $\mathbf{1 0 0}$ \\
\hline
\end{tabular}


Table 10 shows that nearly $91 \%$ of respondents use a traditional budgeting system, while only $9 \%$ did not. This result is unquestionably consistent with other studies (Joshi, 2001; Chenhall and Langfield-Smith, 1998a; Hyvonen, 2005; Burns et al., 2004; Cress and Pettijohn, 1985, AlMeaidi, 2011) regarding the continuing use of traditional budgeting systems in different places around the world.

\subsubsection{The Respondents' Satisfaction with currently used TMATs:}

The last point in this part is to find the respondent's satisfaction with the currently used management accounting tools (that same to be traditional tools), table 11 summarises the findings.

\begin{tabular}{|c|c|c|}
\hline \multicolumn{2}{|c|}{ Table (11) The Respondents' Satisfaction with MA tools used } \\
\hline Degree of satisfaction & Frequency & Percentage \\
\hline Very dissatisfied & 10 & 13.2 \\
\hline Slightly dissatisfied & 14 & 18.4 \\
\hline Moderately satisfied & 16 & 21.1 \\
\hline Reasonably satisfied & 30 & 39.5 \\
\hline Very satisfied & 6 & 100.0 \\
\hline Total & 76 & 3.105 \\
\hline Weighted Mean & Moderately satisfied \\
\hline
\end{tabular}

The data presented in the table 11 shows that about $47.4 \%$ of the respondents indicate that they are very and reasonably satisfied with the current used MA tools; this is considered high percentage of satisfaction with respondents. In the other side $13.2 \%$ of the respondents indicate that they are very dissatisfied, and they require major improvements while 18.4 $\%$ of them are slightly dissatisfied and think that the current used MA tools are still usable, although it needs a lot of improvement. In general, the 
overall weighted mean reflects that on average the respondents are moderately satisfied with a mean of 3.105 and St. deviation of 1.19.

\subsection{Management Accounting Innovations (MAIs):}

MAIs were suggested as alternatives to traditional ones. Twelve MAIs were selected to be investigated through the current research, because most or all of them received much emphasis in several management accounting studies (Drury et al., 1993; Brierley et al., 2007; Abdel- Kader and Luther, 2006; Hyvonen, 2005; Clarke, 1992; Ask and Ax, 1997; Waldron and Everett, 2004; Fullerton and McWatters, 2004; Joshi, 2001; Adler et al., 2000; Chenhall and Langfield-Smith, 1998a, Harris \& Cassidy, 2014), ) and there is no research investigated these twelve tools together in Egyptian business environment before.

\subsubsection{Management Accounting Innovations (MAIs): Current Usage:}

In order to test the usage of MAIs, these MAIs include a twelve MAIs, that mostly studied in literature and cover all the functions of management accounting system regarding costing, controlling, planning, performance management, and evaluation with the whole target is supporting decision making process. Table 12 provide a summary for the respondents' usage of the MAIs.

\begin{tabular}{|c|c|c|c|c|}
\hline \multicolumn{5}{|c|}{ Table (12) The current usage of the MAIs } \\
\hline MAIs & Usage & Frequency & Percent & Rank \\
\hline \multirow{2}{*}{$\begin{array}{l}\text { Activity Based } \\
\text { Costing }\end{array}$} & Currently used & 24 & $31.6 \%$ & \multirow[b]{2}{*}{1} \\
\hline & $\begin{array}{l}\text { Currently not } \\
\text { used }\end{array}$ & 52 & $68.4 \%$ & \\
\hline \multirow{2}{*}{ Target Costing } & Currently used & 15 & $19.7 \%$ & \multirow[b]{2}{*}{4} \\
\hline & $\begin{array}{l}\text { Currently not } \\
\text { used }\end{array}$ & 61 & $80.3 \%$ & \\
\hline \multirow[b]{2}{*}{ Life Cycle Costing } & Currently used & 16 & $21.1 \%$ & \multirow[b]{2}{*}{3} \\
\hline & $\begin{array}{l}\text { Currently not } \\
\text { used }\end{array}$ & 60 & $78.9 \%$ & \\
\hline Kaizen Costing & Currently used & 11 & $14.5 \%$ & 8 \\
\hline
\end{tabular}




\begin{tabular}{|c|c|c|c|c|}
\hline & $\begin{array}{l}\text { Currently not } \\
\text { used }\end{array}$ & 65 & $85.5 \%$ & \\
\hline \multirow[b]{2}{*}{ Backflush Costing } & Currently used & 4 & $5.3 \%$ & \multirow[b]{2}{*}{11} \\
\hline & $\begin{array}{l}\text { Currently not } \\
\text { used }\end{array}$ & 72 & $94.7 \%$ & \\
\hline \multirow{2}{*}{$\begin{array}{l}\text { Quality Costing } \\
\text { Report }\end{array}$} & Currently used & 14 & $18.4 \%$ & \multirow{2}{*}{5} \\
\hline & $\begin{array}{l}\text { Currently not } \\
\text { used }\end{array}$ & 62 & $81.6 \%$ & \\
\hline \multirow{2}{*}{$\begin{array}{l}\text { Throughput } \\
\text { Accounting }\end{array}$} & Currently used & 12 & $15.8 \%$ & \multirow{2}{*}{7} \\
\hline & $\begin{array}{l}\text { Currently not } \\
\text { used }\end{array}$ & 64 & $84.2 \%$ & \\
\hline \multirow{2}{*}{$\begin{array}{l}\text { Value-Based } \\
\text { Management }\end{array}$} & Currently used & 13 & $17.1 \%$ & \multirow{2}{*}{6} \\
\hline & $\begin{array}{l}\text { Currently not } \\
\text { used }\end{array}$ & 63 & $82.9 \%$ & \\
\hline \multirow{2}{*}{$\begin{array}{l}\text { Activity Based } \\
\text { Budgeting }\end{array}$} & Currently used & 21 & $27.6 \%$ & \multirow[b]{2}{*}{2} \\
\hline & $\begin{array}{l}\text { Currently not } \\
\text { used }\end{array}$ & 55 & $72.4 \%$ & \\
\hline \multirow[b]{2}{*}{ Balance Scorecard } & Currently used & 8 & $10.5 \%$ & \multirow{2}{*}{9} \\
\hline & $\begin{array}{l}\text { Currently not } \\
\text { used }\end{array}$ & 68 & $89.5 \%$ & \\
\hline \multirow{2}{*}{$\begin{array}{l}\text { Economic Value } \\
\text { Added }\end{array}$} & Currently used & 7 & $9.2 \%$ & \multirow{2}{*}{10} \\
\hline & $\begin{array}{l}\text { Currently not } \\
\text { used }\end{array}$ & 69 & $90.8 \%$ & \\
\hline \multirow[b]{2}{*}{ Lean Accounting } & Currently used & 3 & $3.9 \%$ & \multirow[b]{2}{*}{12} \\
\hline & $\begin{array}{l}\text { Currently not } \\
\text { used }\end{array}$ & 73 & $96.1 \%$ & \\
\hline
\end{tabular}

Table 12 shows that the most adopted MAIs by respondents in the Egyptian business environment are Activity Based Costing (ABC) and the related budgeting technique which is Activity Based Budgeting (ABB) which adopted by $31.6 \%$ and $27.6 \%$ of respondents respectively. The adoption of these MAIs is high compared with other studies in different 
countries (Emore and Ness, 1991; Waldron and Everett, 2004; Innes and Mitchell, 1995; Innes et al., 2000; Dugdale et al., 2006; Smith et al., 2008; Haldma and Laats, 2002; Ask and Ax, 1997; Clarke et al., 1999; Clarke, 1992; Cinquini et al., 1999; Hyvonen, 2005; Joshi, 1998; Joshi, 2001; Askarany et al., 2007; AL-Meaidi, 2011.

Life Cycle Costing (LCC) adopted by $21.1 \%$ of respondents, the adoption of these MAIs is high compared with other studies in different countries (Waldron and Everett, 2004; Clarke, 1992; Wijewardena and Zoysa, 1999; Adler et al., 2000; Joshi, 2001; Leftesi, A. 2008; AL-Meaidi, 2011).

Target Costing (TC), which is suggested as an alternative to the costplus pricing procedure are adopted by $19.7 \%$ of respondents, this is an acceptable percentage in a developing country, parallel with the findings in Saudi Arabia (Al-Meaidi, 2011), as he found 26.6\% of respondents adopt the TC. The limited use of the TC system in Egypt is in line with the results found in Malaysia, Sweden and Turkey (Smith et al., 2008; Borgernas and Fridthat, 2003; Kocsoy et al., 2008).

Also, findings shows that $18.4 \%$ of respondents used the cost of quality reporting system, these results are in line with the findings found in the USA, Ireland, India, and Saudi Arabia (Clarke, 1992; Adler et al.2000; Joshi, 2001; Waldron and Everett, 2004; Al-Meaidi, 2011).

Other MAIs like, Kaizen Costing, Throughput Accounting, and ValueBased Management are used in firms with percentages of $14.5 \%, 15.8 \%$ \& $17.1 \%$ respectively. This percentage is also acceptable compared to other studies in which the adoption is very low, see for example (Al-Meaidi, 2011; Morisawa and Kurosaki, 2002).

With regards to the extent of usage of the BSC in Egyptian firms, results shows that $10.5 \%$ of respondents are currently using it, and this result is in line with other findings (Nielson and Sorensen, 2004; Arena and Azzone, 2005; Scapens et al., 2003; Abdel-Maksoud et al., 2005, Al-Meaidi, 2011).

There are other MAIs which are rarely adopted by respondents, these MAIs are Backflush costing which adopted by only 5.3\%\% of respondents, and lean accounting which adopted by $3.9 \%$ of respondents. The limited use of the backflush system is consistent with what was found in India, New Zealand and the USA (Joshi, 2001; Adler et al., 2000; Waldron and 
Everett, 2004, this low percentage of usage of Backflush costing and lean accounting, could be due to the limited use of the JIT system.

\section{Conclusion}

This paper aims at exploring the current usage of TMATs and MAIs in the Egyptian manufacturing companies, based on a survey for 76 firms from the public business sector's companies in the Egyptian business environment.

The main findings from the study are that firms are fairly prefer using one accounting system for a variety of purposes over using multiple systems for a specific function each. Also, respondents indicate that product costing system are basically used for external financial reporting and product cost control.

For the usage of TMATs, it is found that firms are still use extensively the traditional tools, as it is found that $58 \%$ of respondents indicated that they use CVP analysis, $75 \%$ of respondents are still use cost-plus technique for pricing, 56.6\% of respondents use the SC system, and $91 \%$ of the respondents are still use the traditional budgeting system.

Also, respondents were asked about their overall satisfaction with the currently used TMATs, $47.4 \%$ of the respondents indicate that they are very and reasonably satisfied with the current used MA tools, and the overall weighted mean reflects that on average the respondents are moderately satisfied with a mean of 3.105 and St. deviation of 1.19 .

Reaching MAIs, which are suggested as alternatives to traditional ones. Twelve MAIs are selected to be investigated through the current research, the most adopted MAIs by respondents in the Egyptian business environment are Activity Based Costing ( $\mathrm{ABC}$ ) and the related budgeting technique which is Activity Based Budgeting (ABB) which adopted by $31.6 \%$ and $27.6 \%$ of respondents respectively. Target Costing (TC) is adopted by $19.7 \%$ of respondents. The relative popularity of $\mathrm{ABC}, \mathrm{ABB}$, LCC, and TC is supported by the fact that they are also the most known MAIs. Therefore, knowledge regarding the MAIs seems to play an important role in their diffusion.

Also, findings show that $18.4 \%$ of respondents use the cost of quality reporting system. Other MAIs like, Kaizen Costing, Throughput Accounting, and Value-Based Management are acceptably used in firms 
with percentages of $14.5 \%, 15.8 \% \& 17.1 \%$ respectively. BSC is used by $10.5 \%$ of respondents, there are other MAIs which are rarely adopted by respondents, these MAIs are Backflush costing which adopted by only $5.3 \% \%$ of respondents, and lean accounting which adopted by $3.9 \%$ of respondents.

To sum up, with the high satisfaction with the currently used TMATs, this give hints that firms may not highly motivated to adopt MAIs, and that TMATs are dominant in the Egyptian companies, and give reflection for the importance of doing a lot of efforts to foster the adoption of the MAIs. However, the adoption rates and of MAIs in Egyptian manufacturing companies is relatively acceptable compared with other developing countries.

\section{References}

1. Abdel-Kader, M., Luther, R., 2008, The impact of firm characteristics on management accounting practices: A UK-based empirical analysis, British Accounting Review, Vol. 40, No. 1, pp. 227.

2. Agbejule, A. (2006). Motivation for activity-based costing implementation: Administrative and institutional influences. Journal of Accounting \& Organizational Change. Vol. 2 Issue: 1, pp.42-73.

3. AL-Meaidi, A. (2011). An investigation into the current management accounting practices and the contingent aspects that have prompted Saudi and non-Saudi manufacturing firms to adopt or not adopt modern management accounting systems: the case of the Eastern Province of Saudi Arabia (Doctoral dissertation, Durham University).

4. Askarany, D. (2003) "An Overview of the Diffusion of Advanced Techniques", pp.225-250, in Tan, B. (Ed) Advanced Topics in Global Information, Vol. 2, IDEA Group Publishing, London

5. Askarany, D. and Smith, M. (2003). "The relationship between Technological Innovation, Activity Based Costing and Business Size", Information Science and Information Technology Education Joint Conference, Pori, Finland, June 24-27 
6. Askarany, D. and Smith, M. (2004) "Contextual Factors and Administrative Changes", Journal of Issues in Informing Science and Information Technology, Vol. 1, pp.179-188

7. Askarany, D., 2002, An investigation into the diffusion of cost and management accounting innovations, Doctoral dissertation, University of South Australia.

8. Askarany, D., Smith, M. and Yazdifar, H. (2007) "Attributes of Innovation and the Implementation of Managerial Tools: An Activity-based Management Technique", International Journal of Business and Systems Research, Vol. 1, No.1 pp. 98-114

9. Ax, C., Bjørnenak, T., 2005, Bundling and diffusion of management accounting innovations - the case of the balanced scorecard in Sweden, Management Accounting Research, 16 (1), pp. 1-20.

10. Ax, C., Greve, J., 2017, Adoption of management accounting innovations: Organizational culture compatibility and perceived outcomes, Management Accounting Research, 34, pp. 59-74

11. Bromwich, M. and Bhimani, A. (1989). Management Accounting: Evolution not Revolution, London: The Chartered Institute of Management Accountants.

12. Busco, C., Quattrone, P., 2015, Exploring How the Balanced Scorecard Engages and Unfolds: Articulating the Visual Power of Accounting Inscriptions, a Contemporary Accounting Research, Vol. 32, No. 3, pp. 1236-1262

13. Cadez, S. \& Guilding, C. (2008): An exploratory investigation of an integrated contingency model of strategic management accounting. In: Accounting, Organizations and Society, Vol. 33, No. 7/8, pp. 836-863.

14. Chandler, A. D. (1990). Strategy and Structure, Massachusetts: MIT Press, $2^{\text {nd }}$ edition.

15. Chiwamit, P., Modell, S., \& Scapens, R. W. (2017). Regulation and adaptation of management accounting innovations: The case of economic value added in Thai state-owned enterprises. Management Accounting Research, 37, 30-48. 
16. Cooper, R. (1988a). "The Rise of Activity-Based Costing-Part One: What Is Activity- Based Cost system?", Journal of Cost Management, Summer, pp. 45-54.

17. Cooper, R. (1988b). "The Rise of Activity-Based Costing-Part Two: When Do I Need an Activity-Based Cost system?", Journal of Cost Management, Fall, pp. 41-48.

18. Cooper, R. (1989a). "The Rise of Activity-Based Costing-Part Three: How many Cost Drivers Do You Need, and How Do you Select Them?", Journal of Cost Management, Winter, pp. 34-46.

19. Cooper, R. (1989b). "The Rise of Activity-Based Costing-Part Four: What Do Activity-Based Costing Systems Look Like?", Journal of Cost Management, Spring, pp. 38-49.

20. Cooper, R. and Kaplan, R.S. (1988) Measure Costs Right: Make the Right Decisions. Harvard Business Review, 66, 96-103.

21. Cooper, R. Kaplan, R. (1992). "Activity-Based Systems: Measuring the Costs of Resource Usage", Accounting Horizons, Vol. 6, Issue 1, pp. 1-13.

22. Cooper, R. Slagmulder, R. (1997). Factors Influencing the Target Costing Process: Lessons from Japanese Practice, Working paper No. 97/30, Department of Economic and Business Administration, University of Ghent, Belgium.

23. Drury C. (2012). Management and Cost Accounting, 8th Edition. UK: Cengage Learning EMEA.

24. Drury, C. (1996), Management Accounting Handbook, ButterworthHeinemann, Oxford

25. Drury, C. (1998) "Recent and Future Development in Management Accounting", Paper Presented to 7th Accounting Congress, Coimbra, Portugal

26. Drury, C. (2004), Management and Cost Accounting, 6th edition, Thomson, London

27. Drury, C. and Tayles, M. (1994) "Product Costing in UK Manufacturing Organizations", The European Accounting Review, Vol. 3, No. 3, pp. $443-469$ 
28. Drury, C. and Tayles, M. (1995) "Issues Arising from Surveys of Management Accounting Practice", Management Accounting Research, Vol. 6, No. 3, pp. 267-280

29. Drury, C. and Tayles, M. (2000) "Cost system Design and Profitability Analysis in UK Companies", Chartered Institute of Management Accountants, London

30. Drury, C., Bround, S., Osborne, P. and Tayles, M. (1993)" A Survey of Management Accounting Practices in UK Manufacturing Companies", ACCA Research Report Association of Certified Chartered Accountants, London

31. Drury, C., Dugdale, D. (1992), "Surveys of management accounting practice", pp.327-347, in Drury, C. (Eds), Management Accounting Handbook, Butterworth-Heinemann, Oxford

32. Guilding, C., Cravens, K. S. and Tayles, M. (2000). "An international comparison of strategic management accounting practices", Management Accounting Research, Vol. 11, Issue 1, pp. 113-135.

33. Heong, A. Y. K., Heang, L. T., Said, J., \& Teng, Y. S. (2013). Adoption, Benefits and Challenges of Strategic Management Accounting Practices: Evidence from Emerging Market. Asia-Pacific Management Accounting Journal, 8(2), 27-45.

34. Islam, M., \& Kantor, J. (2005). The development of quality management accounting practices in China. Managerial Auditing Journal, 20(7), 707-724.

35. Johnson, H. and Kaplan, R. (1987). Relevance Lost: the Rise and Fall of Management Accounting, Boston: Harvard Business School Press.

36. Kaplan, R. S. (1983). "Measuring manufacturing performance: a new challenge to management accounting research", The Accounting Review, Vol. 85, Issue 4, pp. 686-705.

37. Kaplan, R. S. (1984). "The Evolution of Management Accounting", The Accounting Review, Vol. LIX, Issue 3, pp. 390-418.

38. Kaplan, R. S. (1985). Accounting lag: the obsolescence of cost accounting systems, in K. B. Clark et al. (eds): The Uneasy Alliance: 
Managing the Productivity- Technology Dilemma, Boston: Harvard Business School Press.

39. Kaplan, R. S. (1988). "One Cost System Isn't Enough"", Harvard Business Review, January-February, pp. 61-66.

40. Kaplan, R. S. Norton, D. P. (1992). "The Balanced ScorecardMeasures That Drive Performance", Harvard Business Review, January/February, pp. 71-79.

41. Kaplan, R. S. Norton, D. P. (2001). "Transforming the Balanced Scorecard from Performance Measurement to Strategic Management", Accounting Horizons, Vol. 15, Issue 1, pp. 87-104.

42. Kaplan, R. S., \& Norton, David P. (1996). Using the Balanced Scorecard as a Strategic Management System. Havard Business Review, 75-85

43. Leftesi, A. (2008). The diffusion of management accounting practices in developing countries: Evidence from Libya (Doctoral dissertation, University of Huddersfield).

44. Simmonds, K. (1981) Strategic management accounting, Management Accounting (UK), 59 (4): 26-29.

45. Simmonds, K. (1981). The fundamentals of strategic management accounting. London, Institute of Cost and Management Accountants.

46. Sisaye, S., 2015 "Process Innovation and Adaptive Institutional Changes Strategies in Management Control Systems: Activity Based Costing as Administrative Innovation" In Advances in Management Accounting.

47. Tuan Mat, T. Z., \& Smith, M. (2011). Changes in Management Accounting Practices in Malaysia. Asian Review of Accounting, 19(3), 221-242.

48. Yazdifar, D., and Askarany, D., 2010, A comparative investigation into the diffusion of management accounting innovations in the UK, Australia, and New Zealand, Chartered Institute of Management Accountants, Research executive summaries series, Vol 5, Issue 9, pp. 1-11 